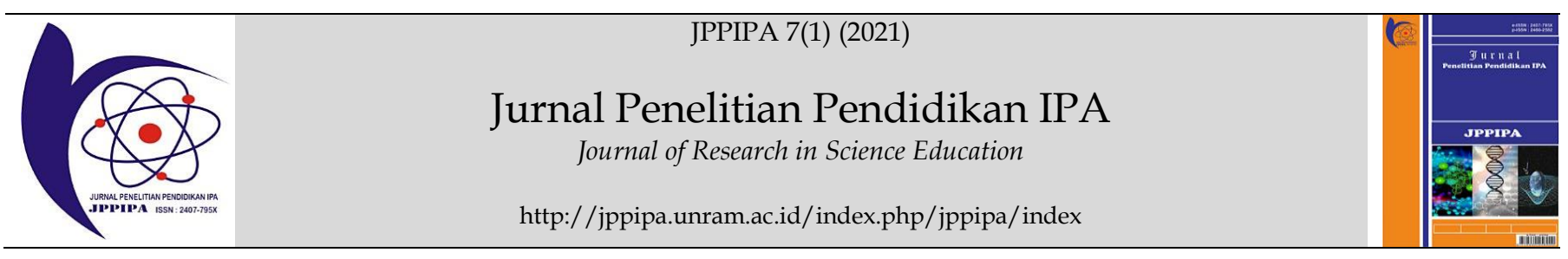

\title{
Differences in Creative Thinking Abilities of High School Students from Village and City
}

\author{
Bowo Sugiharto ${ }^{1 *}$, Elma Rosalia Malinda ${ }^{1}$, Ihrom Rosyadi ${ }^{1}$, Maulidya Dwi Anggini ${ }^{1}$, Nur Rochmah \\ Candra Padmi ${ }^{1}$, Rahmat Evendi ${ }^{1}$
}

${ }^{1}$ Biology Education, Faculty of Teacher Training and Education, Sebelas Maret University, Surakarta, Indonesia.

\section{DOI: 10.29303/jppipa.v7i1.354}

\section{Article Info}

Received: January $2^{\text {th }}, 2020$

Revised: November $2^{\text {th }}, 2020$

Accepted: December 10th, 2020

\begin{abstract}
This study aims to distinguish the creative thinking ability of high school students in Biology subject. This research method uses a quantitative approach and the type of research is descriptive. The population that used was all students of XII MIPA of high school in rural and urban areas by taking a sample of 30 students per each school. The instrument that used was a test of creative thinking ability on chapter 'Animalia' in the form of 40 multiple choice questions that contained indicators of creative thinking ability. This research used descriptive qualitative analysis with data collection techniques using cognitive observation techniques. The results showed that there was a difference between the student's ability to think creatively in rural school (village) and urban school (city).
\end{abstract}

Keywords: Creative thinking ability; senior high school in rural; senior high school in urban.

Citation: Sugiharto, B., Malinda, E., Rosyadi, I., Anggini, M., Padmi, N., \& Evendi, R. (2020). Differences in the Village and City of High School Students 'Creative Thinking Abilities. Jurnal Penelitian Pendidikan IPA, 7(1). doi:https://doi.org/10.29303/jppipa.v7i1.354 .

\section{Introduction}

Biology is a subject in Senior High School that is useful for students' daily lives. The process of learning biology in high school involves students' activeness in thinking so that they can improve their thinking skills and build the concepts they find correctly (Sudjana, 2005). In fact, not all students can build existing concepts, but there are still many students who complain that biology is an eye. difficult subjects due to a lot of material and memorizing and boring. Students are often faced with abstract material concepts, foreign terms, and scientific names as well as systematic calculations on certain materials when studying biology so that biology is considered a difficult subject (Kusuma, et al, 2017).
One of the efforts to increase students' interest in learning biology is to increase the level of student creativity in quality biology learning so that students are expected not only to memorize the material but understand the details of concepts that can be applied in life. Students who have creativity in learning have a high sense of curiosity, characterized by frequently asking good questions, providing many ideas for a problem, and daring to express their opinions (Maya, et al, 2019). Therefore, teachers need to provide good learning conditions that stimulate student creativity.

The ability to think creatively is one of the important abilities for students in accordance with the goals of national education, namely to develop the potential of students to become human beings who fear God Almighty, have a noble character, are knowledgeable, creative, independent, and become 
democratic and responsible citizens. (Sarwinda, 2012), especially in biology learning. Creative thinking requires students to understand and master problems in biology because biology problems include all forms of life on this earth. The ability to think creatively gives students the opportunity to solve problems in their way.

Indicators of the ability to think creatively can be characterized from a cognitive perspective that affects a person's creativity level. The ability to think creatively is a combination of two or more concepts that form a new concept, reveal a new relationship, and be able to see things from a different point of view (Suryadi and Suherman, 2008). The ability to think creatively helps students come up with new ideas based on previous experiences to be able to solve problems in their way. This capability is needed in the discovery of innovations today (Putra, et al, 2016).

Creative thinking skills training is one way to expose students to direct problems and then students are asked to solve problems in different ways. Of course, because of the diversity of students, they will complete the session with different abilities (Mahmudi, 2010).

The fact is that it is not easy to improve creative thinking skills. As many as $44.67 \%$ of students have low-level creative thinking skills (Fardah, 2012). One of the secondary schools obtained an average percentage of students 'creative thinking abilities of $12.88 \%$, so it can be concluded that students' creative thinking skills in high school are classified as low (Meika \& Sujana, 2017).

Creative thinking and student creativity can be influenced by several factors. Factors that can influence students' creative thinking and creativity include environmental factors, intelligence, and open personality (Simonton, 2000). Given the gap between rural and urban areas in terms of stimulation and environmental resources, it is possible that there are systematic differences between students living in rural and urban areas with respect to their creative potential (Li and Ranieri, 2013).

Schools in cities usually have a high quality of education because they have sufficient quantity and quality of teaching staff, complete school facilities, and are able to accept and follow developments in knowledge and technology properly. This is different from the quality of education in village schools. This is mainly due to the lack of teaching staff and inadequate educational facilities. The weakness of the education system in the village itself makes the village unable to deal with the rapid progress of the city. Often the educational development implemented in village schools is not adjusted to the needs of the community, sometimes even the existing education curriculum in the village is equated with the education curriculum in cities even though the conditions of supporting facilities are far different (Anaset al. , 2015).

The catalyst theory presented by McCrae and Ingraham states that the environment will stimulate students' intellect. Students who go to school in cities have an environment that can stimulate openness to creative thinking. However, environmental factors are not enough to be a factor that affects students' creative thinking abilities. There are other factors such as cognitive and personality that can affect the ability to think creatively so that they are able to show a correlation (Shi et al., 2016).

Teachers have a very important role in improving students' creative thinking skills through science-based learning, especially biology. Some of the creative thinking that students have, among others, namely fluency, which means generating new ideas to solve problems, flexibility means that the answers given vary according to the student, originality means authenticity and is unique and different from others, and elaboration means new ideas being developed, adding also can be detailed (Munandar, 2009; Hendriana \& Sumarmo, 2014).

Creative thinking is closely related to the ability to solve problems. Creative thinking is the ability to solve problems in different or new ways (Hwang et al, 2007). Another definition of creative thinking is the ability to solve problems flexibly (Park, 2004).

The purpose of this study was to determine the difference and measure the creative thinking skills between city high school students and village high school students in one of the biology materials. In this study, several problems experienced by students will be revealed to solve the questions in this instrument.

\section{Method}

\section{Research Place}

This research was conducted in one of the Senior High School in the village and Senior High School in the city.

\section{Population and Sample}

The number of samples used was 30 students of class XII MIPA at Senior High School in the city and 30 students of class XII MIPA at Senior High School in the village.

\section{Research procedure}

The procedure used in this test by scoring for the correct answer is 1 . The total score is the number of correct answers calculated by the formula:

Score $=\left(\frac{B}{N}\right) \times 100$

(Mardapi, 2008). 
$\mathrm{B}=$ the number of questions answered correctly

$\mathrm{N}=$ total items

The results obtained, then determined the assessment criteria (Arikunto, 2009), using a letter scale such as:

Table 1: Research Criteria

\begin{tabular}{lcl}
\hline Score & Alphabet & Criteria \\
\hline $80-100$ & A & Very good \\
$66-79$ & B & Good \\
$56-65$ & C & Enough \\
$40-55$ & D & Less \\
$30-39$ & E & Failed \\
\hline
\end{tabular}

\section{Result and Discussion}

Based on the results of research in the city, the results of students' creative thinking abilities, namely:

Table 2. Results of Creative Thinking Ability of Senior High School (SHS) XII Students in the City

\begin{tabular}{lll}
\hline Result & $\begin{array}{l}\text { SHS in the } \\
\text { City }\end{array}$ & $\begin{array}{l}\text { SHS in the } \\
\text { Village }\end{array}$ \\
\hline Maximum score & 57,5 & 70 \\
Minimum score & 7,5 & 27,5 \\
Very good criteria & 0 student & 0 student \\
Good criteria & 0 student & 1 student \\
Enough criteria & 1 student & 1 student \\
Less criteria & 21 student & 17 student \\
Failed criteria & 9 student & 11 student \\
\hline
\end{tabular}

The results of research on creative thinking skills of high school students in the city, it can be seen that students who get the highest score of 57.5 with the criteria for the assessment of $\mathrm{C}$ or Enough. Then, students get the lowest score of one person with a score of 7.5 with the assessment criteria E or Fail. Then 21 students were declared to have the assessment criteria less or D, 9 students who failed the assessment criteria or E, of which 4 people failed in the range (more than or equal to 30-39) and 5 people with fail criteria out of range $(<30-39)$.

Because the number of students who are able to meet the assessment criteria is only 1 person with the remaining 21 people getting less criteria and 9 people getting the failing criteria, high school students in cities have low creative thinking skills.

In contrast to the results of research at high schools in cities, creative thinking skills in rural high schools obtained the results of students who get the highest score of one person with a score of 70 including the assessment criteria B or good. Then the student who gets the lowest score is one person with a score of 27.5 with the E-assessment criteria or fails. Then, students who are declared to have sufficient assessment criteria or $\mathrm{C}$ are 1 person with a score of 60 . Students who are declared to have poor assessment criteria or D are 17 people. The rest are 11 students who have failed assessment criteria or E, namely 10 people who fail within the range (more than or equal to 30-39) and 1 person failing criteria outside the range $(<30-39)$.

Because the number of students who are able to meet the good and sufficient assessment criteria each only amounts to 1 person and the remaining 17 people gets less criteria and 11 people get the failure criteria, then high school students in the village have low creative thinking skills.

Based on the research, it can be seen that there are differences in the ability to think creatively between high school students in cities and villages. This is in line with Li and Naeri's (2013) statement. Even though the measurement results show different numbers, the classification of the measurement results for the creative thinking ability of both urban and rural high school students is classified as low in urban high schools. This can be indicated by the number of students who received the failed assessment criteria in each school amounting to more than 10 students. A striking difference can be seen through the highest score of creative thinking abilities. The high school in the city has the highest score of 57.5 with assessment criteria $C$ or sufficient, while in high school in the village has the highest score of 70 with the assessment criteria B or good.

The significant difference in the level of creative thinking skills between students in the city and the village shows the influence of environmental factors. This statement is in line with the opinion of Simonto (2000). However, the resulting score based on an assessment of the ability to think creatively through questions about Animalia with the nature of multiple choices shows a contradiction. Urban high school students scored lower than rural high school students. With the results of high school student scores in villages that are higher, it can be seen that environmental factors, namely cities do not always show high creative thinking skills. Other factors such as cognitive and personality can affect creative thinking skills which cause high school students in villages to have higher scores (Shi et al., 2016).

Citing the catalyst theory presented by McCrae and Ingraham, the environment will stimulate students' intellect. The statement that students who go to school in cities have an environment that is able to stimulate openness to creative thinking is contrary to the results of the study. This can be due to environmental factors that are not sufficient to be a factor affecting students' creative thinking abilities. There are other factors such as cognitive and personality that can affect the ability to 
think creatively so that they are able to show a correlation (Shi et al., 2016).

Another factor that causes these differences is personality. Gray, Griffin, and Nasta (2005) in OpokuAsare and Siaw (2015) mention the factors that influence the differences in the level of creative thinking skills of rural high schools and city high schools, namely, the characteristics of each child based on the status of the neighborhood, economy, development. social, educational resources, family size, gender, intelligence, and students. One of the factors highlighted in this study is the environment where students live, namely urban and rural environments. Students from urban environments tend to be more creative than students in rural environments. Village students usually tend to be educated in an authoritarian manner, not based on student interests and talents so that they do not stimulate creativity (Tarnoto, 2009). Meanwhile, students from urban environments are educated democratically so that they have freedom in creation and increase student creativity.

Another thing that becomes the difference between students who go to school in villages and cities is the facilities and infrastructure that support learning. Schools in urban environments generally have more adequate facilities that support student creativity with the innovations used in learning, whereas in villages generally only use conventional learning and there are no technological innovations used in learning.

Syah (2014) explains that there are internal and external factors that can affect students 'creative thinking abilities. Internal factors in the form of students' physical or spiritual conditions, external factors such as student environmental conditions, and learning approach factors in the form of learning methods and strategies so that students can understand the lesson and creative thinking. These factors can be one of the influences of students in the village to have higher creative thinking abilities.

Based on the results of this study, geographic factors or school location affect the results of students' creative thinking abilities. All students are able to think creatively, but only some students can maximize their ability to think creatively (Agustina and Noor, 2016).

Abidin (2016) states that the importance of creative thinking skills is to determine whether teacher learning is effective or not. Assessment of creative thinking which includes four indicators, namely the ability to think fluently (fluency), the ability to think flexibly (flexibility), the ability to produce something original (originality), and the ability to elaborate ideas (elaboration) on Animalia class X material, basically done to know the ability of students in solving problems using the concept of creative thinking. Each question that is affixed to the instrument has an indicator of creative thinking. Through the results of research on urban high school students and rural high school students, it can be seen that high school students in cities and villages have not been able to meet the indicators of creative thinking.

\section{Conclusion}

The results of this observation can be concluded that there are differences in the creative thinking abilities of students in high schools in cities and villages. The creative thinking ability of students in cities is classified as lower than students in villages.

\section{Acknowledgments}

The author would like to thank God Almighty and all parties who have participated in the making of this journal.

\section{References}

Abidin, Y. (2016). Revitalisasi Penilaian Pembelajran dalam Konteks Pendidikan Multiliterasi Abad-21. Bandung: Refika Aditama.

Agustina, W., \& Noor, F. (2016). Hubungan hasil belajar dan tingkat berpikir kreatif siswa dalam pembelajaran matematika. Math Didactic: Jurnal Pendidikan Matematika, 2(3), 191-200. https://doi.org/10.33654/math.v2i3.49.

Anas, A.Y,. Riana, A., Wahyudi, A., \& Nurliana, C. (2015). Desa dan Kota dalam Potret Pendidikan. Prosiding KS : Riset dan PKM. 2 (3): 418-422. doi: https://doi.org/10.24198/jppm.v2i3.13592

Arikunto, S. (2016). Dasar-dasar Evaluasi Pendidikan. Jakarta: Bumi Aksara.

Arnyana, I. B. P. (2007). Pengembangan peta pikiran untuk peningkatan kecakapan berpikir kreatif siswa. Jurnal Pendidikan dan Pengajaran UNDIKSHA, 3, 670-683.

Fardah, D.K. (2012). Analisis Proses dan Kemampuan Berpikir Kreatif Siswa dalam Matematika Melalui Tugas Open-Ended. Jurnal Kreano, 3(3), 1-9.

doi:

https://doi.org/10.15294/kreano.v3i2.2616

Hwang, G,J. (2014). Effects of Mobile Learning Time on Students' Conception Of Collaboration, Communication, Complex Problem-Solving, Meta-Cognitive Awareness And Creativity. International Journal of Mobile Learning and Organization, $8(4)$ : $276 . \quad$ doi: $\underline{\text { 10.1504/IJMLO.2014.067029 }}$ 
Kusuma, R.D., Rohman, F., \& Syamsuri, I. (2017). Permasalahan dalam Pembeljaran Biologi pada Jurusan Pertanian SMK Negeri 1 Kademangan Blitar. Prosiding Seminar Nasional III Tahun 2017. 133-136.

Li, Y., \& Ranieri, M. (2013). Educational and Social Correlates of the digital divide for rural and urban children: A study on Primary School Students in A Provincial City of China. Comput. Educ, 60: 197-209. doi: 10.1016/j.compedu.2012.08.001

Mahmudi, A. (2010). Mengukur Kemampuan Berpikir Kreatif Matematis. Konferensi Nasional Matematika XV (pp. 1-9). Manado: Unima Press.

Mardapi, D. (2008). Tekniik Penyusunan Instrumen Tes dan No-tes. Yogyakarta: Mitra Cendikia Offset.

Marwiyah, S., Kamid, \& Risnita. (2015). Pengembangan Instrumen Penilaian Keterampilan Berpikir Kreatif pada Mata Pelajaran IPA Terpadu Materi Atom, Ion, dan Molekul SMP Islam Al Falah. Edu-Sains. 4 (1). doi:https://doi.org/10.22437/jmpmipa.v4i1.236 $\underline{5}$

Maya, A., Ginting, N., \& Tuah, S. (2019). Upaya Meningkatkan Kreativitas Belajar Biologi Siswa Melalui Penerapan Model Pembelajaran Kooperatif Tipe Number Head Together (NHT) Di MAN Siabu. PeTeKa, 2(1), 1-8. doi:http://dx.doi.org/10.31604/ptk.v2i1.1-8.

Meilasari, T. (2018). Pengembangan Asesmen Biologi Berbasis Keterampilan Berpikir Kreatif Pada Materi Animalia Kelas X di SMA Negeri 1 Pangkalan Lampam Oki. Skripsi Pendidikan Biologi UIN Raden Fatah Palembang.

Munandar, U. (2009). Pengembangan Kreativitas Anak Berbakat. Jakarta: Rineka Cipta.

Opoku-Asare, N. A. A., \& Siaw, A. O. (2015). RuralUrban Disparity in Students' Academic Performance in Visual Arts Education: Evidence From Six Senior High Schools in Kumasi, Ghana. SAGE https://doi.org/10.1177/2158244015612523.

Park, H., Ribière, V., \& Schulte, W. D. (2004). Critical attributes of organizational culture that promote knowledge management technology implementation success. Journal of Knowledge Management, $\quad 8(3), \quad 106-117$. https://doi.org/10.1108/13673270410541079

Prasetyo, A. (2016). Perbedaan Kreativitas Siswa SMP di Desa dengan Siswa SMP di Kota. Skripsi Fakultas Psikologi Universitas Muhammadiyah Malang.

Putra, R.D., Rinanto, Y., Dwiastuti, S., \& Rifa'i, I. (2016). Peningkatan Kemampuan Berpikir Kreatif Siswa melalui Model Pembelajaran Inkuiri Terbimbing pada Siswa Kelas XI MIA 1 SMA Negeri Colomadu Karanganyar Tahun Pelajaran 2015/2016. Proceeding Biology Education Conference. 13(1) : 330-334.

Sarwinda, W. (2012). Pemberdayaan Keterampilan Berpikir Kreatif Siswa Melalui Strategi Reciprocal Teaching Pada Pembelajaran Biologi SMA. In Proceeding Biology Education Conference: Biology, Science, Enviromental, and Learning. 10 (2), 254-258.

Shi, B., Dai, D. Y., \& Lu, Y. (2016). Openness to Experience as a Moderator of the Relationship between Intelligence and Creative Thinking: A Study of Chinese Children in Urban and Rural Areas. Frontiers in psychology, 7, 641. https://doi.org/10.3389/fpsyg.2016.00641.

Simonton, D. K. (2000). Creativity: Cognitive, personal, developmental, and social aspects. American Psychologist, 55(1), 151-158. https://doi.org/10.1037/0003-066X.55.1.151.

Sudjana, N. (2005). Penilaian Hasil Proses Belajar Mengajar. Bandung: Remaja Rosdakarya.

Sujana, A. (2017). Kemampuan Berpikir Kreatif dan Pemecahan Masalah Matematis Siswa SMA. Jurnal Penelitian dan Pembelajaran Matematka, 10(2), 8-13. doi: http://dx.doi.org/10.30870/jppm.v10i2.2025

Suryadi, D., \& Herman, T. (2008). Eksplorasi matematika pembelajaran pemecahan masalah. Jakarta: Karya Duta Wahana.

Syah, M. (2014). Psikologi Pendidikan dengan Pendekatan Baru. Bandung: Rosdakarya.

Tarnoto, N., Purnamasari, A. (2009). Perbedaan Kreativitas Siswa SMP N 2 Moyudan Ditinjau dari Tingkat Pendidikan Ibu. Humanitas. 